\title{
molecules
}

ISSN 1420-3049

www.mdpi.com/journal/molecules

Article

\section{Solid Phase versus Solution Phase Synthesis of Heterocyclic Macrocycles}

\section{Seong Jong Kim and Shelli R. McAlpine *}

School of Chemistry, University of New South Wales, Sydney, NSW 2052, Australia

* Author to whom correspondence should be addressed; E-Mail: s.mcalpine@unsw.edu.au;

Tel.: +61-4-1672-8896; Fax: +61-2-9385-4743.

Received: 11 November 2012; in revised form: 10 January 2013 / Accepted: 10 January 2013 /

Published: 16 January 2013

\begin{abstract}
Comparing a solution phase route to a solid phase route in the synthesis of the cytotoxic natural product urukthapelstatin A (Ustat A) confirmed that a solid phase method is superior. The solution phase approach was tedious and involved cyclization of a ridged heterocyclic precursor, while solid phase allowed the rapid generation of a flexible linear peptide. Cyclization of the linear peptide was facile and subsequent generation of three oxazoles located within the structure of Ustat A proved relatively straightforward. Given the ease with which the oxazole Ustat A precursor is formed via our solid phase approach, this route is amenable to rapid analog synthesis.
\end{abstract}

Keywords: urukthapelstatin A; cytotoxic; macrocycle; peptides; heterocycle; thiazole; oxazole; telomestatin; solid phase peptide synthesis

\section{Introduction}

Natural product-based macrocyclic peptides have tremendous potential as drug leads [1-5]. They have numerous pharmacokinetic benefits as drug candidates, including metabolic stability, structural rigidity, high affinity to biological targets and reasonable solubility properties [6,7]. As of 2009, there were 617 peptide drugs or drug candidates, $24 \%$ of these are in clinical trials, $65 \%$ are in advanced preclinical phases, and $11 \%$ are on the market [3]. These peptide drugs are used to treat numerous diseased states including: prostate and breast cancer, HIV infections, osteoporosis, acute coronary syndrome, and they serve as immunosuppressants [8]. Several large peptide-based drugs include: cyclosporin A $(\mathrm{MW}=1,185)$, caspofungin $(\mathrm{MW}=1,093)$, vancomycin $(\mathrm{MW}=1,431)$, and fuzeon 
(MW = 4,492). Cyclosporin $\mathrm{A}$ is an 11 amino acid macrocyclic peptide that is used to suppress the immune system after organ transplants [9]. Caspofungin, vancomycin, and fuzeon are peptide-based antifungal, antibacterial, and anti-HIV drugs, respectively. Aplidine (MW =1,067) is an eight amino acid peptide-based cancer agent that is currently in clinical trials [10-12].

Urukthapelstatin A (Ustat A, Figure 1) falls in a unique class of natural products as it contains directly linked 4,2-azoles [13,14]. Over the last two decades there has been a surge in discoveries of natural products with directly linked azoles, many are now drug candidates [15-17]. Mixed 4,2-bisheterocycle tandem pairs are relatively rare in macrocycles, and thus, urukthapelstatin A represents a unique macrocyclic structure. Ustat A has an average $\mathrm{GI}_{50}$ of $5.6 \mathrm{nM}$ on the Japanese 39 cell line panel $[13,14]$, yet it's mechanism of action remains unknown. As a modified macrocyclic octapeptide, Ustat A resembles several biologically active natural products including: merchercharmycin A (IB-01211), ascidiacyclamide, patellamide D, and telomestatin (Figure 1). IB-01211 was isolated from the marine microorganism strain ES7-008, and it is an antitumor macrocyclic peptide that has an $\mathrm{IC}_{50}=14 \mathrm{nM}$ in Hela S3 cells [18]. The same structure was proposed for merchercharmycin A, which was isolated from a marine-derived Thermoactinomices $s p$. and has an $\mathrm{IC}_{50}=40 \mathrm{nM}$ and $46 \mathrm{nM}$ in A549 cells and Jurkat cells [19] respectively. Ascidiacyclamide is a cytotoxic cyclic peptide with thiazole and methyloxazoline rings [20] and it exhibits cytotoxic activity $\left(\mathrm{IC}_{50}=14 \mu \mathrm{M}\right)$ against leukemia cells [21]. Patellamide D that is a resistance-modifying agent, where it reverses resistance to the anti-cancer agent vinblastine [22]. Finally, the most investigated of these macrocycles is telomestatin. Telomestatin stabilizes the G-quadruplex found in telomeric DNA and inhibits telomerase activity $\left(\mathrm{IC}_{50}=5 \mathrm{nM}\right)$ in numerous cancerous cells, inducing apoptosis [23]. Telomestatin is currently in clinical trials [24]. The interesting biological activity displayed by these heterocycles appears related to their planar aromatic structures, which lend rigidity to the ring and provide sites for binding interactions via pi-stacking.

Figure 1. Ustat $A$ and related structures: merchercharmycin A (IB-01211) [25-27], ascidiacyclamide [20], patellamide $\mathrm{D}$, and telomestatin [25,28].

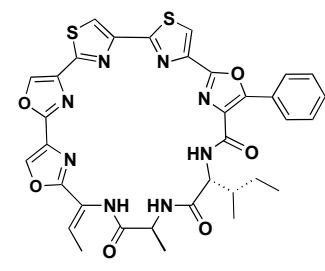

Urukthapelstatin A (Ustat A)

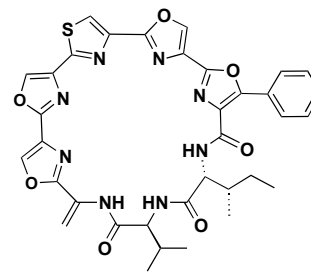

Merchercharmycin A

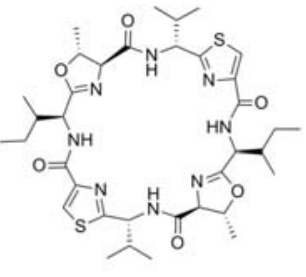

Ascidiacyclamide
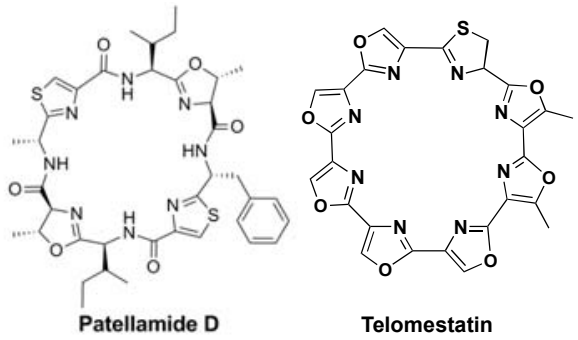

Telomestatin

Depending on the natural product structure, using a solution phase approach can be advantageous over a solid-phase approach [29-38]. Synthesizing Ustat A in solution appeared desirable for several reasons. The first was that the syntheses of merchercharmycin A $[25,26]$ were completed in solution, providing precedent. The second was the ability to explore whether the fragments of the heterocycles were cytotoxic [39]. Our experience and the complexity of Ustat A lead to our decision to initially explore a solution phase synthesis approach [40-48].

However, there are also numerous advantages to utilizing solid phase synthesis in building complex peptide-based macrocycles. Our expertise in solid phase synthesis of cyclic peptides has also been extensive [49-51]. General advantages of solid phase synthesis are easy purification, rapid generation 
of linear peptide intermediates, and precedent in the synthesis of large peptides. Given the ease with which peptide linear precursors are produced on solid phase, we opted to employ this approach in addition to a solution phase method. Should the solid-phase approach work, it would simplify analog synthesis. Thus, exploring the synthesis of the macrocycle Ustat A using both a solution phase and solid phase method provided opportunities to evaluate the benefits of both methods to synthesize this natural product.

\section{Results and Discussion}

\subsection{Synthetic Approach}

Solution synthesis of Ustat A involved cyclization at the peptide bond after forming the linear heterocyclic peptide (Scheme 1A). Formation of the linear precursor involved a modified Hantzsch thiazole reaction between the thioamide and bromoketone (fragments 1 and 2 respectively). Synthesis of fragment 1 entailed cyclization and oxidation of serine residues into oxazoles and the subsequent modified Hantzsch thiazole reaction between ethyl bromopyruvate and the thioamide located on the dioxazole moiety (Scheme 1A). Solid phase synthesis started with an alanine residue attached to a chlorotrityl resin (Scheme 1B). Sequential coupling of residues, cleavage, and cyclization generates a peptide precursor. Subsequent cyclization and oxidation of the serines and cysteines to heterocycles would generate the desired natural product.

Scheme 1. Two synthetic approaches: (A) solution phase and (B) solid phase synthesis of Ustat A.

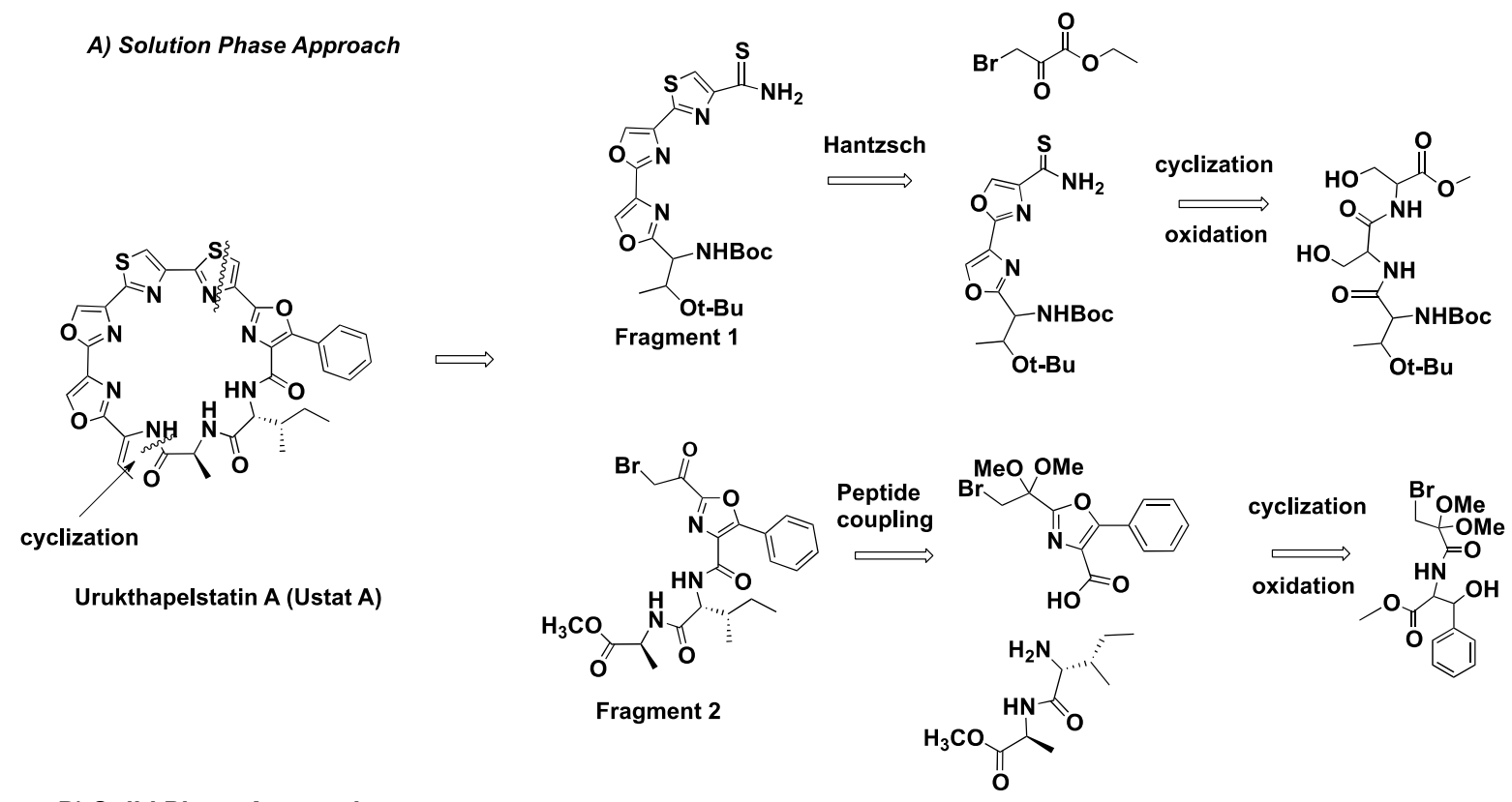

B) Solid Phase Approach
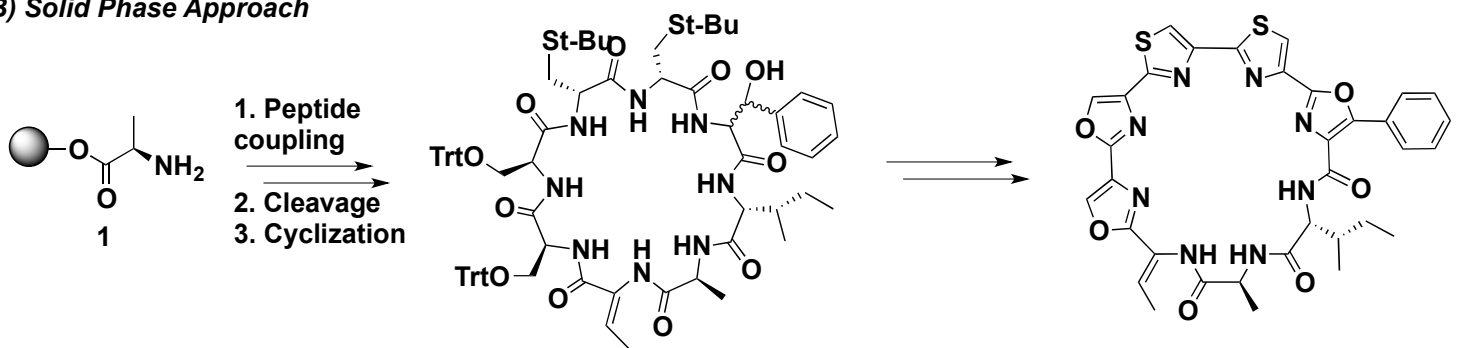

Urukthapelstatin A (Ustat A) 


\subsection{Solution Phase Synthesis}

We have published the formation of the Ustat A linear precursor that was generated in solution [52]. Several macrocyclization trials were performed from $\mathrm{C}$ - and N-deprotected linear precursor using these conditions with activating agents. Initially, cyclization of the macrocycle involved standard coupling conditions developed in our lab (Scheme 2, condition a) [42,50]. However, when these conditions were unsuccessful, we followed the conditions described by Hernandez et al. in the synthesis of merchercharmycin A [25,26,28] (Scheme 2, condition b). These conditions were also unsuccessful, and a closer analysis of Hernandez data on the cyclized product suggests that these conditions were also unsuccessful for synthesizing merchercharmycin A [28]. Additional cyclization conditions were attempted including esters activated by pentafluorophenyl diphenylphosphinate (FDPP) as reported by Joullié et al. (Scheme 2, condition c) [53]. All methods showed no trace of cyclized compound as determined by both LCMS and ${ }^{1} \mathrm{H}-\mathrm{NMR}$. The unsuccessful cyclization of the linear heterocyclic Ustat A precursor using numerous conditions indicated that the sequential heterocycles created a molecule that was too rigid to cyclize with the heterocycles in place.

Scheme 2. Attempted cyclization conditions for the formation of Ustat A.
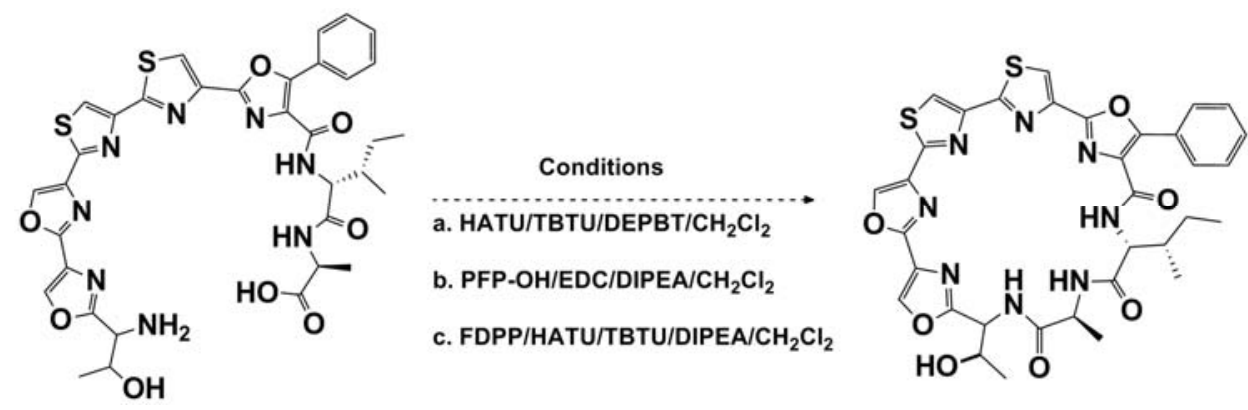

Reagents and conditions: (a) $O$-(Benzotriazol-1-yl)- $N, N, N^{\prime}, N^{\prime}$-tetramethyluronium tetrafluoroborate (TBTU, 0.5 equiv.), 2-(1H-7-azabenzotriazol-1-yl)-1,1,3,3-tetramethyluronium hexafluorophosphate methanaminium (HATU, 0.7 equiv.), 3-(diethoxyphosphoryloxy)-3H-benzo[d][1,2,3] triazin-4-one (DEPBT, 0.5 equiv.), $N, N$-Diisopropylethylamine (DIPEA, 8 equiv.) in DCM $(0.01 \mathrm{M})$; (b) Pentafluoropropanol (2 equiv.), 1-ethyl-3-(3-dimethylaminopropyl)carbodiimide (EDC, 2.5 equiv.), DIPEA (6 equiv.) in DCM $(0.7 \mathrm{mM})$; (c) FDPP (2 equiv.), HATU (0.6 equiv.), TBTU ( 0.6 equiv.), DIPEA (6 equiv.) in DCM $(0.7 \mathrm{mM})$.

\subsection{Solid Phase Synthesis}

Synthesis using solid phase where construction of the heterocycles could be done after formation of the large macrocycle was appealing for three reasons. First, it would offer a simple option for substituting serines for cysteines allowing production of thiazoles in place of oxazoles. Given that thiazole fragments show promising biological activity, exchange of oxazoles for thiazoles is attractive [39]. Second, modification of the amino acids within the peptide region would be straightforward using solid phase, and analogs would be rapidly generated. Rapid production of these compounds provides the opportunity to explore structure activity relationships in biological systems. Third, forming the heterocycles after macrocycle formation allows the choice of sequentially closing the heterocycles, providing synthetic options for forming the final heterocyclic analogs. 
This is the first report of the solid phase synthesis of a Ustat A precursor. Starting with alanine bound to a chlorotrityl resin (1, Scheme 3), we sequentially coupled amino acids using $N$-hydroxy-benzotriazole (HOBt) and diisopropylcarbodiimide (DIC) in DMF and Fmoc removal using 20\% piperidine and 80\% DMF (Scheme 3) [50]. Upon generating the linear precursor on solid phase, cleavage to produce the desired compound 2 occurred using trifluoroethanol (TFE): $\mathrm{CH}_{2} \mathrm{Cl}_{2}$ $(1: 1, \mathrm{v} / \mathrm{v})$ in a $46 \%$ yield. It was characterized by ${ }^{1} \mathrm{H}-\mathrm{NMR}$, indicating we had successfully generated the linear peptide (Scheme 3).

Scheme 3. Synthesis of Ustat A using solid phase.
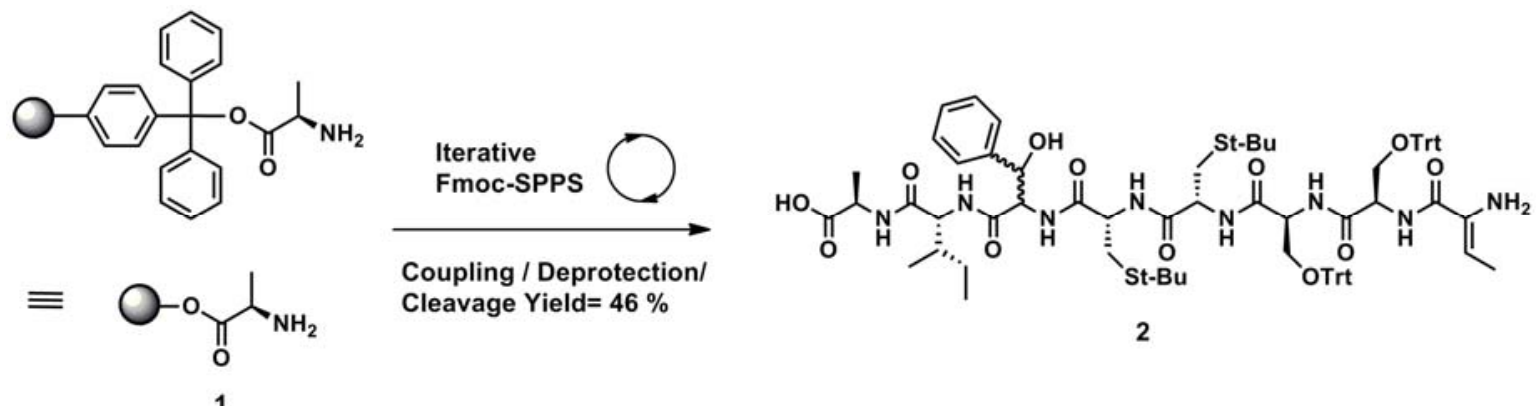

Reagents and conditions: (coupling) Fmoc-Xaa-OH (3 equiv.), HOBt (3 equiv.), DIC (6 equiv.), DMF; (deprotection) 20\% piperidine in DMF; (cleavage) TFE $/ \mathrm{CH}_{2} \mathrm{Cl}_{2}(1: 1, \mathrm{v} / \mathrm{v})$.

Cyclizing the linear precursor 2 utilizing our standard conditions [50] generated the cyclized compound 3 (Scheme 4, yield = 36\%). Employing triethylsilane (TES): $\mathrm{CH}_{2} \mathrm{Cl}_{2}$ with $1.1 \%$ trifluoroacetic acid (TFA) in $\mathrm{CH}_{2} \mathrm{Cl}_{2}$ selectively removed the trityl protecting group (Trt) from serine in the presence of the ${ }^{t} \mathrm{Bu}$ protecting groups on cysteines. Oxazoline formation was carried out by intramolecular cyclodehydration of serines using the fluorinating agent diethylamino sulfurtrifluoride (DAST) and pyridine $/ \mathrm{K}_{2} \mathrm{CO}_{3}$ to afford all three intermediate oxazolines (yield $=47 \%$ ). The oxazolines were oxidized using bromochloroform $\left(\mathrm{BrCCl}_{3}\right)$ and 1,8-diazabicyclo[5,4,0]undec-7-ene (DBU) generating compound 4 .

Scheme 4. Cyclization of the linear precursor.

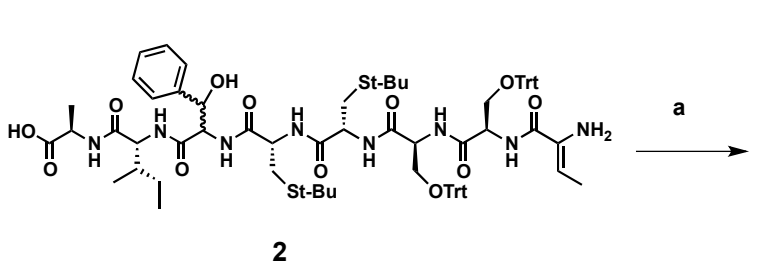

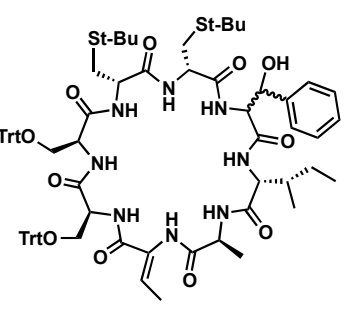

3

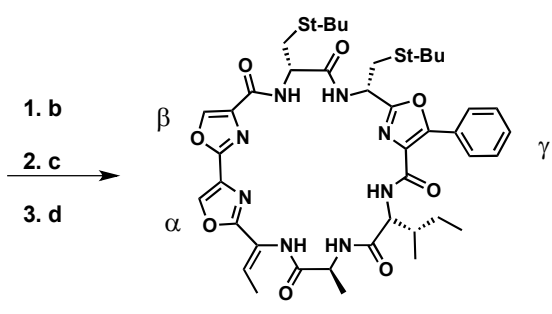

4

Reagents and conditions: (a) HATU (0.5 equiv.), TBTU (0.5 equiv.), ethyl 2-cyano-2(hydroxyimino)acetate (COMU, 0.5 equiv.), 4-(4,6-dimethoxy-1,3,5-triazin-2-yl)-4-methyl morpholinium chloride (DMTMM, 0.5 equiv.), DIPEA (8 equiv.) in $\mathrm{CH}_{2} \mathrm{Cl}_{2}(0.002 \mathrm{M})$; (b) TES/ $\mathrm{CH}_{2} \mathrm{Cl}_{2}(1: 1, \mathrm{v} / \mathrm{v}), 1.1 \% \mathrm{TFA}$ in $\mathrm{CH}_{2} \mathrm{Cl}_{2}$ [54]; (c) DAST (3.5 equiv.), pyridine (3 equiv.), $\mathrm{K}_{2} \mathrm{CO}_{3}$ (1.5 equiv.) in $\mathrm{CH}_{2} \mathrm{Cl}_{2}(0.1 \mathrm{M}),-70{ }^{\circ} \mathrm{C}$; (d) $\mathrm{DBU}$ (6 equiv.), $\mathrm{BrCCl}_{3}$ (6 equiv.) in $\mathrm{CH}_{2} \mathrm{Cl}_{2}$ $(0.1 \mathrm{M}),-40^{\circ} \mathrm{C}$. 


\section{Experimental}

\subsection{Materials}

All reagents and solvents were commercially available and used without further purification. All reactions were carried out with dry solvents under argon. Silica gel 60 (230-400 mesh) was used for thin-layer chromatography (TLC), and flash chromatography. Reactions were monitored by LCMS (Shimadzu Liquid Chromatograph-Mass Spectrometry) or on TLC using UV light as visualizing method and $\mathrm{KMnO}_{4}$, Bromocresol Green, and Ninhydrin as developing agents. All amino acids are commercially available and solid phase reactions were monitored by the ninhydrin test. ${ }^{1} \mathrm{H}$ - and ${ }^{13} \mathrm{C}-\mathrm{NMR}$ spectra were recorded with Bruker Avance III instruments operating at $300 \mathrm{MHz}$ and 600 $\mathrm{MHz}$, respectively. Accurate mass spectra for the novel molecules were recorded using a Thermo LTQ Orbitrap XL high resolution liquid chromatograph-mass spectrometer/mass spectrometer, equipped with a conventional ESI source.

\subsection{Synthesis}

\subsubsection{General Procedure for Solid Couplings}

Solid-phase peptide synthesis was produced manually on $0.08 \mathrm{mmol}$ scale in polypropylene peptide synthesis reaction vessels according to the following general procedures: pre-loaded $N$-deprotected resin was swelled by DMF for $30 \mathrm{~min}$ in the synthesis reaction vessel, drained, then subjected to the following coupling cycle for all standard Fmoc AA's: Fmoc-protected amino acid (3 equiv. relative to resin loading) and HOBt (3 equiv.) dissolved in minimal DMF. DIC (6 equiv.) was added in one portion to resin slurry. The resulting solution was shaken for a minimum of $2 \mathrm{~h}$. Some sample was removed from the resin and washed with IPA. It was checked by the ninhydrin test. Once the $\mathrm{N}$-terminal amino acid residue has been coupled, the peptide-resin is washed with DMF $(3 \times 1 \mathrm{~min})$. The resin was agitated in $20 \%$ piperidine/DMF $(2 \times 10 \mathrm{~min})$, and then washed with DMF $(3 \times 1 \mathrm{~min})$, IPA $(3 \times 1 \mathrm{~min})$, and DMF $(5 \times 1 \mathrm{~min})$. It was also checked by the ninhydrin test.

\subsubsection{Solid Phase Synthesis of Linear Precursor 2}

Resin-bound linear precursor compound was generated following from alanine to (2Z)-2-amino-2butenoic acid via the general procedure for solid coupling method (Section 3.2.1). Ordered Fmoc-AA's: Resin based alanine, D-allo-isoleucine, racemic-phenyl serine, ${ }^{\mathrm{t}} \mathrm{Bu}$-cysteine, ${ }^{\mathrm{t}} \mathrm{Bu}$-cysteine, trityl-serine, trityl-serine, and (2Z)-2-amino-2-butenoic acid [55]. After the last Fmoc deprotection, the resin was washed with DMF $(3 \times 1 \mathrm{~min})$, IPA $(3 \times 1 \mathrm{~min})$ and $\mathrm{MeOH}(3 \times 1 \mathrm{~min})$. The linear peptide was cleaved from the resin by swelling and stirring the resin in a solution of $\mathrm{TFE} / \mathrm{CH}_{2} \mathrm{Cl}_{2}(1: 1, \mathrm{v} / \mathrm{v}$, $10 \mathrm{~mL} / \mathrm{g}$ of dried resin) for $24 \mathrm{~h}$. Cleaved peptide solution was then filtered through a Buchner filter, drained resin was then washed with additional $\mathrm{CH}_{2} \mathrm{Cl}_{2}$ to fully extract cleaved peptide from resin. Solvents were then collected and removed by rotary evaporation and peptide was dried under high vacuum overnight. Dried peptide was then reconstituted with $\mathrm{CH}_{2} \mathrm{Cl}_{2}$ and evaporated multiple times by rotary evaporator before being dried in vacuo overnight to remove residual TFE to give a linear precursor as clear glassy solid to afford compound 2. Yield: $46 \% ;{ }^{1} \mathrm{H}-\mathrm{NMR}\left(300 \mathrm{MH}_{\mathrm{Z}}, \mathrm{Bruker} \mathrm{CDCl}_{3}\right), \delta$ 
7.51-7.08 (m, 35H), $5.46(\mathrm{~m}, 1 \mathrm{H}), 4.73(\mathrm{~m}, 1 \mathrm{H}), 4.58(\mathrm{~m}, 1 \mathrm{H}), 4.58-4.32(\mathrm{~m}, 4 \mathrm{H}), 4.0(\mathrm{q}, 4 \mathrm{H}, J=8.31 \mathrm{~Hz})$, $3.62-3.34(\mathrm{~m}, 3 \mathrm{H}), 3.15$ (q, 4H, $J=7.20 \mathrm{~Hz}), 3.01-2.83(\mathrm{~m}, 3 \mathrm{H}), 2.14(\mathrm{~m}, 1 \mathrm{H}), 2.01-1.78(\mathrm{bs}, 2 \mathrm{H}), 1.68$ $(\mathrm{s}, 3 \mathrm{H}), 1.40-1.25(\mathrm{~m}, 18 \mathrm{H}), 1.05-1.02(\mathrm{~m}, 3 \mathrm{H}), 0.87-0.85(\mathrm{~m}, 3 \mathrm{H}) ;{ }^{13} \mathrm{C}-\mathrm{NMR}(300 \mathrm{MHz}$, Bruker, $\mathrm{CDCl}_{3}$ ), $\delta$ 197.9, 172.1-169.5 (peptide amide $\mathrm{C}=\mathrm{O}$ ), 143.1, 128.4-126.3 (aromatic carbons, trityl), 126.1, 87,4, 72.4, 62.4, 60.4, 55.2, 54.7, 43.5 (peptide aliphatic carbons), $30.97\left({ }^{\mathrm{t}} \mathrm{Bu}-\mathrm{CH}_{3}\right), 25.9,22.1$, 17.6, 13.8, 11.3, 6.7 (peptide aliphatic carbons); LCMS (ESI): calcd for $\mathrm{C}_{80} \mathrm{H}_{96} \mathrm{~N}_{8} \mathrm{O}_{12} \mathrm{~S}_{2} \mathrm{Na}^{+}\left[\mathrm{M}+\mathrm{Na}^{+}\right]$ 1448.78, found 1448.70; $\mathrm{HRMS}(\mathrm{ESI})$ : calcd for $\mathrm{C}_{80} \mathrm{H}_{97} \mathrm{~N}_{8} \mathrm{O}_{12} \mathrm{~S}_{2}\left[\mathrm{M}+\mathrm{H}^{+}\right]$1425.6667, found 1425.6443.

\subsubsection{Synthesis of the Cyclized Compound $\mathbf{3}$}

The cyclized compound 3 was synthesized using linear compound $2(0.8 \mathrm{~g})$ in $\mathrm{CH}_{2} \mathrm{Cl}_{2}(280 \mathrm{~mL}$, $2 \mathrm{mM}$ ) with HATU (0.10 g, 0.5 equiv.), TBTU (0.09 g, 0.5 equiv.), DMTMM (0.07 g, 0.5 equiv.), COMU ( $0.11 \mathrm{~g}, 0.5$ equiv.) as the coupling reagents with anhydrous DIPEA ( $0.78 \mathrm{~mL}, 8$ equiv.). The reaction mixture was stirred at room temperature for $6 \mathrm{~h}$. Upon completion, the reaction was washed with aqueous $\mathrm{HCl}$ solution $(\mathrm{pH}=1,50 \mathrm{~mL} \times 2)$, and saturated aqueous $\mathrm{NaHCO}_{3}$ solution $(50 \mathrm{~mL} \times 2)$. The collected organic layer was dried over $\mathrm{Na}_{2} \mathrm{SO}_{4}$ and concentrated in vacuo. The obtained crude residue was purified by flash column chromatography (silica gel, EtOAc/hexanes) to yield the desired cyclized compound $\mathbf{3}$ as a yellow oil $(28 \mathrm{mg})$. The cyclization reaction to afford compound $\mathbf{3}$ was found to be rapid and efficient by LCMS analysis. Yield: $36 \%$; ${ }^{1} \mathrm{H}-\mathrm{NMR}\left(300 \mathrm{MHz}, \mathrm{CDCl}_{3}\right.$, $) \delta 7.51-7.10$ (m, 35H), $5.40(\mathrm{~m}, 1 \mathrm{H}), 4.81(\mathrm{~m}, 1 \mathrm{H}), 4.70(\mathrm{~m}, 1 \mathrm{H}), 4.36-4.21(\mathrm{~m}, 4 \mathrm{H}), 4.20-3.91(\mathrm{~m}, 4 \mathrm{H}), 3.56-3.34$ (m, 3H), 3.17-2.86 (m, 7H), 2.38-2.33 (m, 1H), $2.01(\mathrm{~s}, 3 \mathrm{H}), 1.62(\mathrm{~m}, 2 \mathrm{H}), 1.40-1.25(\mathrm{~m}, 18 \mathrm{H})$, 0.93-0.88 (m, 6H); ${ }^{13} \mathrm{C}-\mathrm{NMR}\left(600 \mathrm{MHz}\right.$, Bruker, $\mathrm{CDCl}_{3}$ ), $\delta$ 176.8-171.2 (peptide amide $\mathrm{C}=\mathrm{O}$ ), 146.8, 131.6-125.7 (aromatic carbons, trityl), 120.5, 115.1, 66.6, 60.4, 56.9, 54.4, 48.8, 43.9, 36.7, 32.6 (peptide aliphatic carbons), $29.4\left({ }^{\mathrm{t}} \mathrm{Bu}-\mathrm{CH}_{3}\right), 27.1,25.2,22.7,20.6,14.2$ (peptide aliphatic carbons); LCMS (ESI): calcd for $\mathrm{C}_{80} \mathrm{H}_{95} \mathrm{~N}_{8} \mathrm{O}_{11} \mathrm{~S}_{2}\left[\mathrm{M}+\mathrm{H}^{+}\right]$1408.78, found 1408.95; HRMS(ESI): calcd for $\mathrm{C}_{80} \mathrm{H}_{94} \mathrm{~N}_{8} \mathrm{O}_{11} \mathrm{~S}_{2} \mathrm{Na}[\mathrm{M}+\mathrm{Na}]$ 1429.6381, found 1429.6691.

\subsubsection{Synthesis of Oxazole-based Macrocycle 4}

Selective removal of Trts: compound $3(0.28 \mathrm{~g})$ was diluted to a $0.1 \mathrm{M}$ solution in $\mathrm{TES} / \mathrm{CH}_{2} \mathrm{Cl}_{2}$ $(1: 1, \mathrm{v} / \mathrm{v})$, followed by the addition of $1.1 \% \mathrm{TFA}$ in $\mathrm{CH}_{2} \mathrm{Cl}_{2}$ until colorless. The reaction was performed at room temperature for $3 \mathrm{~h}$. Upon completion, the reaction mixture was dried, and concentrated to afford the alcohol (quantitative yield).

Oxazoline formation: 3.5 equiv. of DAST $(0.14 \mathrm{~mL})$ were added dropwise to the serine macrocyclic compound in $\mathrm{CH}_{2} \mathrm{Cl}_{2}(3.0 \mathrm{~mL}, 0.1 \mathrm{M})$ at $-70{ }^{\circ} \mathrm{C}$ under Ar. The reaction mixture was stirred for $1 \mathrm{~h}$, followed by the addition of pyridine ( 3 equiv., $0.07 \mathrm{~mL}$ ), and $\mathrm{K}_{2} \mathrm{CO}_{3}$ (1.5 equiv., $0.06 \mathrm{~g}$ ) and stirred for an additional $30 \mathrm{~min}$. The solution was then allowed to room temperature for $12 \mathrm{~h}$. Upon completion, the organic solution was partitioned between saturated aqueous $\mathrm{NaHCO}_{3}$ and $\mathrm{CH}_{2} \mathrm{Cl}_{2}$. The solvent was removed and the residue was purified by flash column chromatography.

Oxazole formation: Oxidation of the oxazoline fragment was performed with $\mathrm{DBU}$ (6 equiv., $0.29 \mathrm{~mL}$ ) in $\mathrm{CH}_{2} \mathrm{Cl}_{2}$ at $-40{ }^{\circ} \mathrm{C}$. The solution was stirred for $15 \mathrm{~min}$ and $\mathrm{BrCCl}_{3}$ (6 equiv., $0.21 \mathrm{~mL}$ ) were then added to the reaction mixture, which was allowed to proceed over $12 \mathrm{~h}$. The reaction was worked up using aqueous $\mathrm{HCl}$ solution $(\mathrm{pH}=1,50 \mathrm{~mL} \times 2)$, and saturated aqueous $\mathrm{NaHCO}_{3}$ solution $(50 \mathrm{~mL} \times 2)$. 
The solvent was removed and the residue was purified by flash column chromatography to afford compound 4. Yield: 56\% (2 step); ${ }^{1} \mathrm{H}-\mathrm{NMR}\left(600 \mathrm{MHz}, \mathrm{CDCl}_{3}\right), \delta$ 7.38-7.24 (m, 5H), 7.19-7.17 (d, $2 \mathrm{H}, J=7.48 \mathrm{~Hz}), 5.38(\mathrm{~m}, 1 \mathrm{H}), 4.39-4.18(\mathrm{~m}, 2 \mathrm{H}), 4.17-4.06(\mathrm{~m}, 2 \mathrm{H}), 4.05-3.91(\mathrm{~m}, 4 \mathrm{H}), 2.36$ $(\mathrm{s}, 3 \mathrm{H}), 2.06(\mathrm{~m}, 1 \mathrm{H}), 1.80-1.61(\mathrm{~m}, 3 \mathrm{H}), 1.50(\mathrm{~m}, 2 \mathrm{H}), 1.40-1.25(\mathrm{~m}, 18 \mathrm{H}), 0.93-0.88(\mathrm{~m}, 6 \mathrm{H})$; ${ }^{13} \mathrm{C}-\mathrm{NMR}\left(600 \mathrm{MHz}\right.$, Bruker, $\left.\mathrm{CDCl}_{3}\right), \delta 173.5(\mathrm{C}=\mathrm{O}), 165.9(\mathrm{C}=\mathrm{O}), 146.8,143.9$ (oxazoles-CH), 134.2, 129.5, 129.4-126.3 (aromatic carbons, trityl), 68.1, 67.7, 56.8, 38.9, 34.5, 31.4 (peptide aliphatic carbons), $29.7\left({ }^{\mathrm{t}} \mathrm{Bu}-\mathrm{CH}_{3}\right), 28.9,24.5,23.8,14.1,11.0$ (peptide aliphatic carbons); LCMS (ESI): calcd for $\mathrm{C}_{42} \mathrm{H}_{54} \mathrm{~N}_{8} \mathrm{O}_{8} \mathrm{~S}_{2} \mathrm{Na}^{+}\left[\mathrm{M}+\mathrm{Na}^{+}\right]$886.05, found 886.10; HRMS(ESI): calcd for $\mathrm{C}_{42} \mathrm{H}_{55} \mathrm{~N}_{8} \mathrm{O}_{8} \mathrm{~S}_{2}\left[\mathrm{M}+\mathrm{H}^{+}\right]$863.3584, found 863.3579.

\section{Conclusions}

We have developed a solid phase method for generating the potential anticancer lead Ustat A. Solid phase is superior to solution phase as it rapidly generates a flexible linear precursor. The linear peptide is easily cyclized (yield $=36 \%$ ) and conversion of the serines and phenylserine to oxazoles is straightforward. Formation of the thiazoles remains, and synthetic studies to this end are ongoing. In addition, biological evaluation of intermediates $\mathbf{2 - 4}$ are in progress and will be reported in due course.

\section{Supplementary Materials}

Supplementary materials can be accessed at: http://www.mdpi.com/1420-3049/18/1/1111/s1.

\section{Acknowledgments}

We thank the University of New South Wales for a scholarship to S.J.K. and support of this research. We thank NIH 1R01CA137873 for providing reagents for this project.

\section{References and Notes}

1. Jarvis, L.M. Breakthroughs in manufacturing are making large-scale synthesis of peptides a viable proposition. C E News 2006, 84, 23-25.

2. Chatterjee, J.; Gilon, C.; Hoffman, A.; Kessler, H. N-Methylation of peptides: A new perspective in medicinal chemistry. Acc. Chem. Res. 2008, 41, 1331-1342.

3. Danho, W.; Swistok, J.; Khan, W.; Chu, X.; Cheung, A.; Fry, D.; Sun, H.; Kurylko, G.; Rumennik, L.; Cefalu, J.; et al. Opportunities and challenges of developing peptide drugs in the pharmaceutical industry. In Peptides for Youth, Proceedings of the 20th American Peptide Symposium, Montreal, Canada, 23-28 June 2007; Valle S.D., Escher E., Lubell W.D., Eds.; Springer: New York, NY, USA, 2009; Volume 611, pp. 467-469.

4. Fletcher, J.M.; Hughes, R.A. Modified low molecular weight cyclic peptides as mimetics of BDNF with improved potency, proteolytic stability and transmembrane. Bioorg. Med. Chem. 2009, 17, 2695-2702.

5. Wiesner, J.; Vilcinskas, A. Antimicrobial peptides, the ancient arm of the human immune system. Virulence 2010, 1, 440-464.

6. Fairlie, D.P.; Abbenante, G.; March, D.R. Macrocyclic peptidomimetics-Forcing peptides into bioactive conformations. Curr. Med. Chem. 1995, 2, 654-686. 
7. Koehn, F.E.; Carter, G.T. The evolving role of natural products in drug discovery. Nat. Rev. Drug Discov. 2005, 4, 206-220.

8. Loffet, A. Peptides as Drugs: Is there a Market? Eur. Pept. Soc. 2002, 8, 1-7.

9. Starzl, T.E.; Klintmalm, G.B.; Porter, K.A.; Iwatsuki, S.; Schroter, G.P. Clinical trials of cyclosporin A. N. Engl. J. Med. 1981, 305, 266-269.

10. Faivre, S.; Chieze, S.; Delbaldo, C.; Ady-Vago, N.; Guzman, C.; Lopez-Lazaro, L.; Lozahic, S.; Jimeno, J.; Pico, F.; Armand, J.P.; et al. Phase I and pharmacokinetic study of aplidine, a new marine cyclodepsipeptide in patients with advanced malignancies. J. Clin. Oncol. 2005, 23, 7871-7880.

11. Maroun, J.A.; Belanger, K.; Seymour, L.; Matthews, S.; Roach, J.; Dionne, J.; Soulieres, D.; Stewart, D.; Goel, R.; Charpentier, D.; et al. Phase I study of Aplidine in a daily35 one-hour infusion every 3 weeks in patients with solid tumors refractory to standard therapy. A National Cancer Institute of Canada Clinical Trials Group study: NCIC CTG IND 115. Ann. Oncol. 2006, 17, 1371-1378.

12. Le Tourneau, C.; Raymond, E.; Faivre, S. Aplidine: A paradigm of how to handle the activity and toxicity of a novel marine anticancer poison. Curr. Pharm. Des. 2007, 13, 3427-3429.

13. Matsuo, Y.; Kanoh, K.; Imanaka, H.; Adachi, K.; Nishizawa, M.; Shizuri, Y. Urukthapelstatin A, a novel cytotoxic substance from marine-derived Mechercharimyces asporophorigenes YM11-542 II physcico-chemical properties and structural elucidation. J. Antibiot. 2007, 60, 256-260.

14. Matsuo, Y.; Kanoh, K.; Yamori, T.; Kasai, H.; Katsuta, A.; Adachi, K.; Shin-ya, K.; Shizuri, Y. Urukthapelstatin A, a novel cytotoxic substance from marine-derived Mechercharimyces asporophorigenes YM11-542 I fermentation, isolation, and biological properties. J. Antibiot. 2007, 60, 251-255.

15. Irschik, H.; Reichenbach, H.; Hofle, G.; Jansen, R. The thuggacins, novel antibacterial macrolides from sorangium cellulosum acting against selected gram-positive bacteria. J. Antibiot. 2007, 60, 733-738.

16. Riego, E.; Hernández, D.; Albericio, F.; Álvarez, M. Directly linked polyazoles: Important moieties in natural products. Synthesis 2005, 2005, 1907-1922.

17. Ying, Y.; Taori, K.; Kim, H.; Hong, J.; Luesch, H. Total synthesis and molecular target of Largazole, a histone deacetylase inhibitor. J. Am. Chem. Soc. 2008, 130, 8455-8459.

18. Romero, P.; Malet, L.; Canedo, L.; Maria, C.C.; Fernando, R.J. New cytotoxic depsipeptides. WO 2005/000880 A2, 2005.

19. Kanoh, K.; Matsuo, Y.; Adachi, K.; Imagawa, H.; Nishizawa, M.; Shizuri, Y. Mechercharmycins $\mathrm{A}$ and B, cytotoxic substances from marine-derived thermoactinomyces sp. YM3-251. J. Antibiot. 2005, 58, 289-292.

20. Ishida, T.; Inoue, M.; Hamada, Y.; Kato, S.; Shioiri, T. X-ray crystal structure of ascidiacyclamide, a cytotoxic cyclic peptide from ascidian. J. Chem. Soc. Chem. Commun. 1987, 370-371.

21. Asano, A.; Minoura, K.; Yamada, T.; Numata, A.; Ishida, T.; Doi, M.; Katsuya, Y.; Mezaki, Y.; Sasaki, M.; Taniguchi, T.; et al. Effect of asymmetric modification on the conformation of ascidiacyclamide analogs. J. Pept. Res. 2002, 60, 10-22.

22. Williams, A.B.; Jacobs, R.S. A marine natural product, patellamide D, reverses multidrug resistance in a human leukemic cell line. Cancer Lett. 1993, 71, 97-102. 
23. Miyazaki, T.; Pan, Y.; Joshi, K.; Purohit, D.; Hu, B.; Demir, H.; Mazumder, S.; Okabe, S.; Yamori, T.; Viapiano, M.S.; et al. Telomestatin impairs glioma stem cell survival and growth through the disruption of telomeric G-quadruplex and inhibition of the proto-oncogene, c-Myb. Clin. Cancer Res. 2012, 18, 1268-1280.

24. Telomestatin. Available online: http://www.clinicaltrials.gov (accessed on 1 October 2012).

25. Hernandez, D.; Riego, E.; Albericio, F.; Alvarez, M. Synthesis of natural product derivatives containing 2,4-concatenated oxazoles. Eur. J. Org. Chem. 2008, 3389-3396.

26. Hernandez, D.; Vilar, G.; Riego, E.; Canedo, L.M.; Cuevas, C.; Albericio, F.; Alvarez, M. Synthesis of IB-01211, a cyclic peptide containing 2,4-concentrated thia- and oxazoles, vix Hantzsch macrocyclization. Org. Lett. 2007, 9, 809-811.

27. Shin-ya, K.; Wierzba, K.; Matsuo, K.; Ohtani, T.; Yamada, Y.; Furihata, K.; Hayakawa, Y.; Seto, H. Synthesis of Telomerastatin. J. Am. Chem. Soc. 2001, 123, 1262-1263.

28. Hernandez, D.; Riego, E.; Francesch, A.; Cuevas, C.; Albericio, F.; Alvarez, M. Preparation of pentaazole containing cyclopeptides: challenges in macrocyclization. Tetrahedron 2007, 63, 9862-9870.

29. Ward, D.E.; Gai, Y.; Lazny, R.; Pedras, M.S.C. Probing Host-selective Phytoxicity: Synthesis of Destruxin B and several natural analogues. J. Org. Chem. 2001, 66, 7832-7840.

30. Tarver, J.; Pfizenmayer, A.J.; Joullié, M.M. Total synthesis of comformationally constrained Didemnin B analogues. Replacement of $\mathrm{N}, \mathrm{O}$-dimethyltyrosine with L-1,2,3,4-tetrahydroisoquinoline and L-1,2,3,4-tetrahydro-7-methoxyisoquinoline. J. Org. Chem. 2001, 66, 7575-7587.

31. Li, W.R.; Ewing, W.R.; Harris, B.D.; Joullié, M.M. Total synthesis and structural investigations of didemnins A, B, and C. J. Am. Chem. Soc. 1990, 112, 7659-7672.

32. Mayer, S.C.; Ramanjulu, J.; Vera, M.D.; Pfizenmayer, A.; Joullié, M.M. Synthesis of new didemnin B analogs for investigations of structure/biological activity relationships. J. Org. Chem. 1994, 59, 5192-5205.

33. Vera, M.D.; Pfizenmayer, A.J.; Ding, X.; Ahuja, D.; Toogood, P.L.; Joullié, M.M. Synthesis and biological evaluation of didemnin photoaffinity analogues. Bioorg. Med. Chem. Lett. 2001, 11, 1871-1874.

34. Vera, M.D.; Pfizenmayer, A.J.; Ding, X.; Xiao, D.; Joullié, M.M. [Lys3]didemnins as potential affinity ligands. Bioorg. Med. Chem. Lett. 2001, 11, 13-16.

35. Xiao, D.; Vera, M.D.; Liang, B.; Joullié, M.M. Total synthesis of a conformationally constrained didemnin B analog. J. Org. Chem. 2001, 66, 2734-2742.

36. Ramanjulu, J.; Ding, X.; Li, W.R.; Joullié, M.M. Synthesis of a reduced ring analog of Didemnin B. J. Org. Chem. 1997, 62, 4961-4969.

37. Kopp, F.; Stratton, C.F.; Akella, L.B.; Tan, D.S. A diversity-oriented synthesis approach to macrocycles via oxidative ring expansion. Nat. Chem. Biol. 2012, 8, 358-365.

38. Campbell, F.; Kilner, C.A.; Wilson, A.J. Expedient synthesis of benzene tricarboxamide macrocycles derived from p-aminobenzoic acid. Tetrahedron Lett. 2010, 51, 1361-1363.

39. Kim, S.J.; Lin, C.-C.; Pan, C.-M.; Rananaware, D.P.; Ramsey, D.M.; McAlpine, S.R. A structure-activity relationship study of compounds containing sequential oxazoles and thiazoles. Med. Chem. Commun. 2012, in press.

40. Carroll, C.L.; Johnston, J.V.C.; Kekec, A.; Brown, J.D.; Parry, E.; Cajica, J.; Medina, I.; Cook, K.M.; Corral, R.; Pan, P.-S.; et al. Synthesis and cytotoxicity of novel Sansalvamide A derivatives. Org. Lett. 2005, 7, 3481-3484. 
41. Styers, T.J.; Kekec, A.; Rodriguez, R.A.; Brown, J.D.; Cajica, J.; Pan, P.-S.; Parry, E.; Carroll, C.L.; Medina, I.; Corral, R.; et al. Synthesis of Sansalvamide A derivatives and their cytotoxicity in the colon cancer cell line HT-29. Bioorg. Med. Chem. 2006, 14, 5625-5631.

42. Styers, T.J.; Rodriguez, R.A.; Pan, P.-S.; McAlpine, S.R. High-yielding macrocyclization conditions used in the synthesis of novel Sansalvamide A derivatives. Tetrahedron Lett. 2006, 47, 515-517.

43. Rodriguez, R.A.; Pan, P.-S.; Pan, C.-M.; Ravula, S.; Lapera, S.A.; Singh, E.K.; Styers, T.J.; Brown, J.D.; Cajica, J.; Parry, E.; et al. Synthesis of second generation Sansalvamide A derivatives: Novel templates as potent anti-tumor agents. J. Org. Chem. 2007, 72, 1980-2002.

44. Singh, E.K.; Ravula, S.; Pan, C.-M.; Pan, P.S.; Vasko, R.C.; Lapera, S.A.; Weerasinghe, S.V.W.; Pflum, M.K.H.; McAlpine, S.R. Synthesis and biological evaluation of histone deacetylase inhibitors that are based on FR235222: A cyclic tetrapeptide scaffold. Bioorg. Med. Chem. Lett. 2008, 18, 2549-2554.

45. Davis, M.R.; Styers, T.J.; Rodriguez, R.A.; Pan, P.-S.; Vasko, R.C.; McAlpine, S.R. Synthesis and cytotoxicity of a new class of potent decapeptide macrocycles. Org. Lett. 2008, 10, 177-180.

46. Singh, E.K.; Nazarova, L.A.; Lapera, S.A.; Alexander, L.D.; McAlpine, S.R. Histone deacetylace inhibitors: Synthesis of cyclic tetrapeptides and their triazole analogs. Tetrahedron Lett. 2010, 51, 4357-4360.

47. Davis, M.R.; Singh, E.K.; Wahyudi, H.; Alexander, L.D.; Kunicki, J.; Nazarova, L.A.; Fairweather, K.A.; Giltrap, A.M.; Jolliffe, K.A.; McAlpine, S.R. Synthesis of Sansalvamide A peptiodmimetics: Trizaole, oxazole, thiazole, and pseudoproline containing compounds. Tetrahedron 2012, 68, 1029-1051.

48. Singh, E.; Ramsey, D.M.; McAlpine, S.R. Total synthesis of natural product trans,trans- Sanguinamide B and its structurally related conformational analogs. Org. Lett. 2012, 14, 1198-1201.

49. Alexander, L.D.; Sellers, R.P.; Davis, M.E.; Ardi, V.C.; Johnson, V.A.; Vasko, R.C.; McAlpine, S.R. Evaluation of Di-sansalvmide A derivatives: Synthesis, structure-activity relationship, and mechanism of action. J. Med. Chem. 2009, 52, 7927-7930.

50. Sellers, R.P.; Alexander, L.D.; Johnson, V.A.; Lin, C.-C.; Savage, J.; Corral, R.; Moss, J.; Slugocki, T.S.; Singh, E.K.; Davis, M.R.; et al. A third generation of Sansalvamide A derivatives: Design and synthesis of Hsp90 Inhibitors. Bioorg. Med. Chem. 2010,18, 6822-6856.

51. Ramsey, D.M.; McConnell, J.R.; Alexander, L.D.; Tanaka, K.W.; Vera, C.M.; Mcalpine, S.R. A new Hsp90 inhibitorthat exhibits a novel biological profile. Bioorg. Med. Chem. Lett. 2012, 22 , 3287-3290.

52. Pan, C.-M.; Lin, C.-C.; Kim, S.J.; Sellers, R.P.; McAlpine, S.R. Progress toward the synthesis of Urukthapelstatin A and two analogues. Tetrahedron Lett. 2012, 53, 4065-4069.

53. Joullié, M.M.; Lassen, K.M. Evolution of amide bond formation. ARKIVOC 2010. 8, 189-250.

54. Barlos, K.; Gatos, D.; Koutsogianni, S. Fmoc/Trt-amino acids: Comparison to Fmoc/tBu-amino acids in peptide synthesis. J. Pept. Res. 1998, 51, 194-200.

55. All AA's were commercially available from Chem-impex, polypeptide, and GL Biochem.

Sample Availability: Samples of the compounds are available from the authors.

(C) 2013 by the authors; licensee MDPI, Basel, Switzerland. This article is an open access article distributed under the terms and conditions of the Creative Commons Attribution license (http://creativecommons.org/licenses/by/3.0/). 